\title{
Strategi Guru Bimbingan dan Konseling Dalam Meningkatkan Pengamalan Ibadah Siswa
}

\author{
Inggra Fadillah ${ }^{1}$, Dodi Pasila Putra ${ }^{2}$, Yeni Afrida $^{3}$ \\ IAIN Bukittinggi ${ }^{1,23}$, Indonesia \\ @ Inggrafadillah23@gmail.com ${ }^{1}$
}

Submitted: 09-11-2020
Revised: 11-11-2020
Accepted:06-07-2021
Copyright holder:
@ Fadhillah, I., Putri, D., \& Afrida, Y. (2021)
First publication right:
@ Ghadian Jurnal Bimbingan Konseling \&
Kemasyarakatan
How to cite:
Fadhillah, l., Putri, D., \& Afrida, Y. (2021). Strategi Guru
Bimbingan dan Konseling Dalam Meningkatkan
Pengamalan Ibadah Siswa. Ghaidan: Jurnal Bimbingan
Konseling Islam Dan Kemasyarakatan, 5(1), 13-20.
https://doi.org/https://doi.org/10.19109/ghaidan.v5i
1.6899
Published by:
UIN Raden Fatah Palembang
Journal website:
https://Ghadian.co.id/index.php/bcp
E-ISSN:
2621-8283

2621-8283

\section{PENDAHULUAN}

ABSTRACT:

As for the background of the authors conducting this research is the existence of some students who have not prayed properly such as not hastening to the mosque or mushalla after the call to prayer, $I$ did not do the tahiyyatul prayer before sitting, most students prefer to do other activities, many also learners who perform prayers by force and are still lazing in the classroom despite being reprimanded by the homeroom teacher, not a few students who still took time to the canteen. Application or process (deed) fulfill (obligation, duty). From the research carried out, it can be seen that the Guidance and Counseling teacher strategy in providing an understanding of the practice of the students' prayers has gone quite well by providing material about prayer in general to students in accordance with the material students have learned. The research method by the author is one of the descriptive qualitative field research. This research was conducted on students of class VIII at MTsN 2 Bukittinggi. The key informants were guidance and counseling teachers and supporting informants for PAl students and teachers. The author collects data with observation, interview and documentation techniques. Data processing techniques using qualitative descriptive analysis and techniques to test the validity of the data with data triangulation.

KEYWORDS: Guidance and counseling strategy, Practicing prayers

Manusia diciptakan Tuhan dalam bentuk yang amat baik. Sesudah ditiupkan roh ke dalam tubuhnya, para malaikat disuruh sujud (memberi hormat) kepadanya. Tuhan memberi manusia ilmu pengetahuan dan kemauan, dijadikan khalifah (penguasa) di bumi dan menjadi pusat kegiatan di alam ini. Segala apa yang ada di langit dan di bumi, semuanya bekerja untuk kepentingan manusia, dan kepadanya diberikan hikmat lahir dan bathin. ${ }^{1}$ Dalam perkembangannya, manusia selalu didorong oleh keinginannya, baik yang di timbulkan dari dalam dirinya sendiri maupun dari luar, untuk menciptakan dan mewujudkan sejarahnya. Karena manusia dalam menghadapi alam butuh sebuah upaya untuk mengubahnya sehingga alam bisa dilestarikan dengan hadirnya manusia ke muka bumi dan alam pun mempunyai arti dan peran bagi keberlangsungan hidup manusia di dunia. 
Oleh karena itu, hadirnya manusia di muka bumi ini tidak lain hanyalah untuk beribadah kepada Allah SWT. ${ }^{2}$ Sebagaimana perintah Allah ta'ala dalam dalam Q.S (Adz-Dzariat: 56 ).

Tugas utama manusia diciptakan di bumi ini untuk beribadah hanya kepada Allah sedangkan tujuan yang lain adalah sebagai pelengkap atas tujuan di atas, dan juga manusia dituntut untuk selalu berbuat baik kepada sesama saling tolong menolong dan tidak mengharapkan apapun dari orang lain tersebut melainkan semata hanya karena Allah. Ibadat atau ibadah merupakan sebuah kata yang diambil dari bahasa Arab. Dalam terminologi bahasa Indonesia kata ini memiliki arti perbuatan atau penyataan bakti terhadap Allah atau Tuhan yang didasari oleh peraturan agama. Segala usaha lahir dan batin yang sesuai perintah agama yang harus dituruti pemeluknya. Indikasi ibadah adalah kesetiaan, kepatuhan dan penghormatan serta penghargaan kepada Allah SWT serta dilakukan tanpa adanya batasan waktu. ${ }^{3}$

Ibadah juga diartikan secara sederhana sebagai pesembahan, yaitu sembahan manusia kepada Allah SWT. Karena itu, ibadah bisa berarti menghambakan diri kepada Allah SWT. Telah dikemukakan sebelumnya bahwa bagi orang yang percaya (iman) kepada Allah SWT, detak napas dan gerak langkah serta segala aktivitas yang dilakukannya, diniatkan sebagai wujud dedikasinya terhadap Allah SWT. Jadi perbuatan apapun yang dilakukan seorang muslim selama itu baik dan diniatkan hanya karena Allah SWT, maka perbuatan tersebut bernilai ibadah di sisi Allah SWT. ${ }^{4}$ Sebagaimana yang telah dijelaskan dalam Al-Qur'an surat Al-An'am ayat 162-163. Ibadah adalah semua yang mencakup segala perbuatan yang disukai dan dirihai oleh Allah SWT, baik berupa perkataan maupun perbuatan, baik terang-terangan maupun tersembunyi dalam rangka mengagungkan Allah SWT dan mengharapkan pahala-Nya dan mengamalkan dalam kehidupan sehari-hari, dan juga sebagai sarana berkomunikasi dengan Allah SWT atas nikmat yang sudah diberikan tiada hentinya.

Menurut Kamus Besar Bahasa Indonesia, pengamalan adalah proses, cara perbuatan mengamalkan, melaksanakan, pelaksanaan dan penerapan. Sedangkan pengamalan dalam dimensi keberagamaan adalah sejauh mana implikasi ajaran agama mempengaruhi seseorang dalam kehidupan sosial. Dimensi pengamalan menunjukkan pada seberapa tingkatan muslim berprilaku dimotivasi oleh ajaran-ajaran agamanya, yakni bagaimana individu berelasi dengan dunianya terutama dengan manusia lain. ${ }^{5}$ Pengamalan adalah dari kata dasar "amal", yang mempunyai arti perbuatan baik yang mendatangkan pahala (menurut ketentuan agama islam), sedangkan pengamalan itu sendiri mempunyai arti proses (perbuatan) melaksanakan; pelaksanaan; penerapan atau proses (perbuatan) menunaikan (kewajiban, tugas). ${ }^{6}$

Dapat dipahami bahwa pengamalan ibadah adalah suatu proses usaha yang dilakukan seseorang untuk memperoleh suatu perubahan tingkah laku yang baru secara keseluruhan, sebagai hasil pengamalannya sendiri sehingga akan mendatangkan pahala dan kebiasaan baik dalam melakukan ibadah. Sesungguhnya salah satu ibadah yang sangat penting dalam islam adalah shalat.

\footnotetext{
${ }^{2}$ Aswat, Manusia Ideal Dalam Pemikiran Muhammad lqbal (skripsi), Universitas Islam Negeri Sunan Kalijaga Yogyakarta, 2010, $\mathrm{hlm} 2$

${ }^{3}$ Muhaimin, Tadjab, ABD. Mudjid, Dimensi-Dimensi Studi Islam, (Surabaya: Karya Abditama, 1994), hlm. 256.

${ }^{4}$ Mahfud Rois, Pendidikan Agama Islam , (Jakarta: Erlangga, 2011), hlm. 23

${ }^{5}$ WJS Poerwadaminta, Kamus Besar Bahasa Indonesia (Jakarta: Balai Pustaka. 1085), hlm. 33.

${ }^{6}$ Peyusun kamus Pusat Pembinaan dan Pengembangan Bahasa, Op.Cip hlm.,25
} 
Shalat memiliki kedudukan istimewa baik dilihat dari cara memperoleh perintahnya yang dilakukan secara langsung. Hakekat ibadah shalat ialah menghadapkan jiwa dan hati seseorang kepada Allah SWT, yang mendatangkan rasa takut dan patuh (taqwa) kepada kebesaran dan kekuasaan-Nya dengan penuh khusuk. Ibadah shalat adalah wujud penghambaan diri seorang muslim yang beriman dan bertaqwa kepada Allah SWT, dengan menghadap jiwa dan raga yang diawali dengan takbir dan diakhiri dengan salam, dengan memenuhi rukun dan syarat-syarat tertentu untuk menghadapkan keridhoan dari-Nya. ${ }^{7}$

Kedudukan shalat dalam agama islam yaitu sebagai ibadah yang menempati posisi yang tidak dapat digantikan oleh ibadah apa pun juga, shalat merupakan tiang agama. Ibadah shalat merupakan ibadah yang paling penting dari pada ibadah-ibadah yang lain. Ibadah shalat merupakan ibadah yang penting, antara lain karena tegak tidaknya Islam seseorang itu terletak pada pelaksanaan ibadah shalatnya, baik buruknya amal perbuatan seseorang itu terletak pada baik buruknya shalat, dengan mendirikan shalat akan selalu mendapatkan rahmat Allah SWT, serta shalat merupakan pembuka pintu surga. Pentingnya shalat itu pada dasarnya adalah untuk manusia itu sendiri. Oleh karena itulah maka Allah mewajibkan setiap manusia yang diciptakan-Nya untuk beribadah (shalat) kepada-Nya. ${ }^{8}$ Adapun manfaat dari melaksanakan shalat antara lain yaitu mengajarkan bagaimana agar kita selalu mengawali suatu perbuatan dengan niat yang baik, dan ini bisa tercermin dari sebelum memulai shalat kita harus selalu mengawalinya dengan niat. Selain itu manfaat shalat yang lainnya yaitu dapat memperkuat iman, membangun akhlak yang baik dan moralitas yang tinggi, mengajarkan tentang kesabaran, serta dapat mencegah dari segala perbuatan yang keji dan mungkar.

\section{METODE}

Pada penelitian ini, peneliti menggunakan jenis penelitian lapangan field research yaitu mengumpulkan data langsung dari lokasi penelitian. Sedangkan pendekatan dalam penelitian ini adalah penelitian kualitatif deskriptif. Adapun yang menjadi lokasi penelitian penulis adalah MTsN Negeri 2 Bukittinggi yang beralamat di Jalan Panorama Baru, Panganak, Bukittinggi. Yang menjadi responden disini adalah satu orang guru BK, satu orang guru PAI dan dua orang siswa. Untuk mengungkapkan permasalahan di atas, maka penulis mengumpulkan data melalui penelitian lapangan, yaitu penulis terjun langsung ke lapangan untuk mengamati sekaligus mengumpulkan data yang menunjang serta berkaitan dengan masalah yang dibahas, melalui observasi dan wawancara serta studi dokumentasi. Setelah data terkumpul melalui observasi, wawancara dan studi dokumentasi, kemudian penulis akan mengolah data dengan menggunakan teknik analisis deskriptif analitik, maksudnya data yang diperoleh tidak dituangkan dalam bentuk angka statistik atau bilangan melainkan dalam bentuk kualitatif yang memiliki arti lebih kaya dari sekedar angka. Peneliti segera melakukan analisis data dengan memberikan pemaparan gambaran mengenai situasi yang diteliti dalam bentuk naratif.

\footnotetext{
${ }^{7}$ Tim alkarima, Aku Senang Belajar Fiqih kelas 1,Arafah Mitra Utama, 2004, hlm. 123.

${ }^{8}$ Zakiah, Darajad, 2000. Shalat Menjadikan Hidup Tentram. Jakarta: CV. Ruhama. HIm. 54.
} 


\section{HASIL DAN PEMBAHASAN}

Berdasarkan hasil penelitian, peneliti menemukan strategi yang diberikan guru bimbingan dan konseling dalam meningkatkan pengamalan ibadah shalat zuhur siswa di MTsN 2 Bukittinggi, dapat peneliti jabarkan hasil penelitian sebagai berikut:

1. Memberikan pemahaman tentang pentingnya shalat

Hal pertama yang dilakukan oleh guru BK dalam meningkatkan pengamalan ibadah shalat adalah memberikan pemahaman tentang pentingnya shalat. Informasi ini diperoleh dari wawancara dengan guru BK, guru PAI dan siswa. Kedudukan shalat dalam agama islam yaitu sebagai ibadah yang menempati posisi yang tidak dapat digantikan oleh ibadah apapun juga, shalat merupakan tiang agama. Ibadah shalat merupakan ibadah yang paling penting dari pada ibadah-ibadah yang lain. Ibadah shalat merupakan ibadah yang penting, antara lain karena tegak tidaknya islam seseorang itu terletak pada pelaksanaan ibadah shalatnya, baik buruknya amal perbuatan seseorang itu terletak pada baik buruknya shalat, dengan mendirikan shalat akan selalu mendapatkan rahmat Allah SWT. ${ }^{9}$

Pemberian materi tentang pentingnya shalat akan memberikan penguatan kepada siswa yang pengamalan ibadah shalatnya masih kurang bagus di sekolah, sebab bisa jadi siswa tersebut kekurangan pengetahuan agama mengenai shalat. Jadi dengan pemberian materi tersebut siswa jadi mengetahui apa kegunaan shalat yang wajib orang islam lakukan dan dapat mengubah kebiasaan yang kurang baik selama ini. Sesuai dengan hasil observasi dan wawancara di atas terungkap bahwa salah satu strategi yang dilakukan guru bimbingan dan konseling dalam meningkatkan pengamalan ibadah shalat siswa adalah dengan memberikan pemahaman tentang pentingnya shalat terhadap siswa. Walaupun pemahaman yang diberikan oleh guru bimbingan tersebut dijelaskan secara ringkas tapi guru PAI ada menjelaskannya secara sempurna di jam pelajaran agama berlangsung.

2. Memberikan layanan tentang pengetahuan agama

IImu pengetahuan didapat oleh manusia melalui proses belajar dan pengalaman yang ia rasakan dalam hidupnya sehari. Bahkan pengetahuan agama ini sendiri didapat oleh manusia dengan menjembatani ilmu pengetahuan. Manusia tidak akan bisa menganut agama dengan baik kalau tidak ada ilmu pengetahuan yang menjadi jembatan untuk menuju suatu agama yang diyakini, yang dapat membedakan mana yang termasuk perbuatan baik dan buruk serta mengamalkan semua perintah dengan baik. ${ }^{10}$ Begitu pula dengan kurangnya pengetahuan agama tentang ibadah shalat apabila seseorang tersebut tidak paham maka orang tersebut melaksanakan ibadahnya dengan tidak sempurna.

Maka untuk itu pentingnya pengetahuan agama pada generasi muda ialah untuk mewujudkan generasi yang kaya akan pengetahuan agama yang sesuai dengan perintah Allah Swt. Berdasarkan hasil observasi dan wawancara di atas terungkap bahwa, dengan adanya pelaksanaan bimbingan konseling yang dilakukan oleh guru BK, dapat memberikan pengetahuan atau hal-hal baru kepada siswa untuk diterapkan dikehidupan sehari-harinya. Karena manusia itu

\footnotetext{
9'Zakiah, Darajad, 2000. Shalat Menjadikan Hidup Tentram. Jakarta: CV. Ruhama. HIm. 54.

${ }^{10}$ Samhi Muawan Djamal, Penerapan Nilai-nilai Ajaran Islam dalam Kehidupan Masyarakat di Desa Garuntungan Kecamatan Kindang Kabupaten Bulukumba, (Makassar: Universitas Islam Negeri), HIm. 168.
} 
dilahirkan dalam keadaan tidak mengetahui apapun, kemudian Allah SWT menugaskan manusia untuk mencari tahu. Kemudian apabila dia mempunyai niat untuk memperdalam ilmu agamanya, dengan seiring berjalannya waktu ia akan mengerti dan mengamalkannya. Begitu juga dengan guru bimbingan konseling dan guru PAI memberikan layanan tentang pengetahuan agama.

3. Memberikan layanan tentang akibat meninggalkan shalat

Sebagaimana diketahui bahwa shalat adalah merupakan pokok ajaran agama. Untuk mewajibkan ibadah shalat, Allah SWT langsung memanggil Rasulullah SAW ke langit melalui peristiwa isra mi'raj. Shalat suatu kewajiban yang harus dilakukan oleh umat islam yang telah memenuhi syarat. ${ }^{11}$ Para ulama bersepakat bahwa meninggalkan shalat termasuk dosa besar bahkan lebih besar dari dosa berzina dan mencuri.

Keefektifan setiap layanan yang diberikan oleh guru bimbingan konseling didukung oleh pelaksanaan layanan itu sendiri, baik itu cara penyampaian layanan, materi layanan, teknik, pendekatan yang dilakukan guru bimbingan konseling dalam pemberian layanan sehingga layanan yang diberikan dapat menarik keingintahuan siswa terhadap isi layanan tersebut. Dari hasil observasi dan wawancara di atas dapat penulis simpulkan bahwa dalam memberikan pengajaran guru BK dan guru PAI memberikan pengajaran yang baik sesuai dengan tingkah laku siswa tersebut. Dan juga apapun kesalahan yang dilakukan siswa, siswa harus siap menerima konsekuensinya. Begitu juga dengan pemberian materi tentang akibat meninggalkan shalat, siswa akan merasa takut apabila masih lalai dalam melaksanakan shalat karena sudah mengetahui konsekuensi yang akan diterimanya.

4. Memberikan materi tentang dampak dari teman sebaya

Hubungan remaja dengan orang tuanya mulai berpindah ke teman sebaya. Teman sebaya merupakan tempat berbagi perasaan dan pengalamannya. Tekanan untuk mengikuti teman sebaya menjadi sangat kuat pada masa remaja. Jika konformitas itu berbentuk positif, remaja akan mengadopsi hal-hal positif pula yang sangat mempengaruhi masa pembentukan identitasnya. Sebaliknya, jika konformitasnya bersifat negatif, remaja dapat dengan mudah terbawa pada prilaku kurang baik. ${ }^{12}$

Masa remaja merupakan masa yang sangat penting dalam proses perkembangan. Karena itu perkembangan pada masa remaja sudah seharusnya mendapatkan perhatian dari berbagai pihak, terutama dari lingkungan terdekatnya seperti keluarga. Pengaruh teman sebaya dalam pengembangan dan pembentukan identitas dirinya tidak bisa dianggap tidak penting karena dengan teman sebayalah biasanya remaja banyak menghabiskan waktunya untuk saling bertukar informasi tentang dunia luarnya. Hal ini akan berpengaruh pada pemikiran remaja dalam mengembangkan siapa dirinya dan apa yang harus ia lakukan. Adapun faktor yang mempengaruhi merupakan dorongan untuk meniru orang lain, misalnya dalam hal tingkah laku, dan pengaruh psikis baik yang datang dari orang lain dan dapat diterima tanpa adanya kritik orang lain. ${ }^{13}$

\footnotetext{
${ }^{11}$ Deden Suparman, Pembelajaran Ibadah Shalat Dalam Perspektif Psikis dan Medis, HIm. 48.

${ }^{12}$ Martha Julia Mukiwanti, Pengaruh Konformitas Pada Kelompok Teman Sebaya Terhadap Tinggi Rendahnya Kedisiplinan Shalat Siswa Kelas X Jurusan Teknik Permesinan di SMK N 1 Semarang (skripsi), Universitas Islam Negeri Walisongo, 2019 , hlm. 5.

${ }^{13}$ Martha Julia Mukiwanti, Pengaruh Konformitas Pada Kelompok Teman Sebaya Terhadap Tinggi Rendahnya Kedisiplinan Shalat Siswa Kelas X Jurusan Teknik Permesinan di SMK N 1 Semarang (skripsi), Universitas Islam Negeri Walisongo, 2019, hlm. 6.
} 
Dari hasil observasi dan wawancara di atas dapat penulis simpulkan bahwa dalam memberikan pengajaran guru BK memberikan pengajaran yang baik sesuai dengan tingkah laku siswa tersebut. Begitu juga dengan memberikan pembahasan tentang dampak teman sebaya, yang mana teman sebaya bukan cuma memberikan dampak positif terhadap remaja lain tapi juga bisa memberikan banyak dampak negatif, termasuk juga pengamalan shalat di sekolah karena ikut-ikutan teman yang malas sehingga remaja lain terpengaruh untuk malas melaksanakan shalat.

\section{Memberikan materi tentang kewajiban sebagai umat islam}

Sebagai seorang muslim tentunya ada kewajiban-kewajiban yang harus kita lakukan. Salah satu kewajiban tersebut berupa kewajiban kita akan shalat. Shalat merupakan salah satu rukun islam yang lima. Dan barang siapa yang melaksanakannya maka ia mendapatkan pahala. Begitupun sebaliknya barang siapa yang meninggalkannya maka ia mendapatkan dosa. ${ }^{14}$ Jadi, dari uraian di atas dapat disimpulkan bahwa apabila siswa tersebut sudah mengetahui apa-apa saja kewajiban nya selaku umat islam ia akan melakukannya dengan sungguh-sungguh tanpa ada paksaan dari pihak mana pun, maksud nya siswa tersebut akan melaksanakan kewajibannya atas kesadaran diri.

6. Memberikan materi tentang dampak game online terhadap ibadah siswa

Bermain game online sangat berpengaruh terhadap pengamalan ibadah shalat. Karena dengan seringnya bermain game online maka shalat menjadi sering ditinggalkan dan tidak membuat orang yang mengerjakan shalat menjadi lebih rajin. Orang akan lebih tertarik untuk bermain dibandingkan dengan melaksanakan shalat walaupun terlambat, namun bisa jadi mereka akan meninggalkan shalat hanya karena bermain game. ${ }^{15}$ Bermain game online juga membuatnya menjadi tidak khusyu' dalam melaksanakan shalat, karena terkadang ia masih merasa terganggu dengan bayangan game yang ia mainkan. Selain itu ia menjadi tidak khusyu' karena hanya untuk memenuhi perintah orang tua atau gurunya saja untuk shalat. ${ }^{16}$ Jadi, dari uraian di atas dapat disimpulkan bahwa game online dapat menimbulkan efek ketagihan, yang berakibat melalaikan kehidupan nyata dan mengenyampingkan tugas-tugas penting lainnya tidak terkecuali dalam hal ibadah. Juga bisa membuat orang menjadi terisolir dengan lingkungan sekitar, ini merupakan efek karena terlalu seringnya bermain game sehingga menjadi lupa dengan hubungan sosial dalam kehidupannya.

7. Pemahaman tentang hikmah yang terdapat dalam shalat

Shalat adalah tiang agama. Shalat memiliki hikmah yang begitu mendasar. la berfungsi sebagai tonggak tegaknya bangunan hidup serta bangunan megah yang memiliki sejuta ruang yang dibutuhkan bagi kehidupan dengan segala sendi-sendinya. Bagi yang mengerjakannya, shalat akan menorehkan kedamaian dan ketenangan dalam kalbu, tak gampang goncang dan menggerutu apabila ada musibah yang menimpa. Bahkan, ia akan segera menyadari dengan kesadaran yang teramat dalam bahwa segala yang merundung manusia adalah cobaan dari sang

\footnotetext{
${ }^{14}$ Musleh Al Hayubi. Kewajiban Shalat Bagi Seorang Muslim. Sekolah Tinggi Teknologi Nurul Jadid, 2012, hlm. 1.

${ }^{15}$ Fina Hilmuniati, Dampak Game Online dalam Pengamalan Ibadah Shalat pada Anak, Universitas Islam Negeri Syarif Hidayatullah, 2011, hlm. 45.

${ }^{16}$ Fina Hilmuniati, Dampak Game Online dalam Pengamalan Ibadah Shalat pada Anak, Universitas Islam Negeri Syarif Hidayatullah, 2011, hlm. 46
} 
pencipta. ${ }^{17}$ Sebelum guru BK memberikan materi terkait layanan yang ia berikan kepada siswa, guru BK harus melihat terlebih dahulu materi apa yang cocok dan sesuai dengan apa yang terjadi di lapangan sehingga materi yang diberikan kepada siswa saling berkesinambungan.

Tuhannya. Jadi mudah-mudahan setelah diberikan pemahaman tentang hikmah shalat bisa mengubah kebiasaan buruknya. Tapi walaupun saya tidak memberikan materi tersebut guru agama pasti ada membahas mengenai itu." ${ }^{18}$ Berdasarkan hasil wawancara di atas di MTsN 2 Bukittinggi terungkap bahwa dengan adanya pelaksanaan bimbingan dan konseling yang dilakukan guru BK cukup dapat membantu siswa dalam mengatasi kebiasaan buruk nya dalam beribadah, sehingga nantinya pada saat jam istirahat shalat siswa sudah atas kesadarannya sendiri pergi ke mesjid untuk melaksanakan shalat tanpa di pantau-pantau lagi.

\section{KESIMPULAN}

Berdasarkan hasil dari deskripsi dan pembahasan pada bab sebelumnya, maka dapat disimpulkan ada beberapa strategi yang diberikan guru bimbingan dan konseling dalam meningkatkan pengamalan ibadah shalat zuhur siswa di MTsN 2 Bukittinggi yaitu, 1) memberikan pemahaman tentang pentingnya shalat 2) memberikan layanan tentang pengetahuan agama, 3) Memberikan layanan tentang akibat meninggalkan shalat 4) Memberikan materi tentang dampak dari teman sebaya 5) Memberikan materi tentang kewajiban sebagai umat islam 6) Memberikan materi tentang dampak game online terhadap ibadah shalat 7) Pemahaman tentang hikmah yang terdapat dalam shalat.

\section{REFERENSI}

Abdul Aziz Muhammad Azzam dan Abdul Wahhab Sayyed Hawwas (2010) Fiqih Ibadahcet ke-2. Jakarta: Amzah.

Asy'arie, Musa (1999) Filsafat Islam Sunnah Nabi Dalam Berfikir, 'Yogyakarta: Lesfi.

Aswat (2010) Manusia Ideal Dalam Pemikiran Muhammad Iqbal (skripsi), Universitas Islam Negeri Sunan Kalijaga. Yogyakarta.

Daradjat,Zakiah (1984) Dasar-Dasar Agama Islam. Jakarta: Bulan Bintang.

Darajad, Zakiah (2000) Shalat Menjadikan Hidup Tentram. Jakarta: CV. Ruhama.

Hayubi, Musleh Al (2012) Kewajiban Shalat Bagi Seorang Muslim. Sekolah Tinggi Teknologi Nurul Jadid.

Hilmuniati, Fina (2011) Dampak Game Online dalam Pengamalan Ibadah Shalat pada Anak. Universitas Islam Negeri Syarif Hidayatullah.

Herdiansyah, Haris (2013) Wawancara Observasi, dan Focus Groups, Penggalian Data Kualitatif. Raja Gravindo.

Insa, Dedi (2016) Korelasi Antara Tingkat pengamalan Ibadah Shalat dengan Kedisiplinan Siswa Kelas IV di Madrasah Ibtidaiyah Ismaria Al-Qur'aniyyah Raja Basa Bandar Lampung (skripsi). Lampung: Institut Agama Islam Negeri Lampung.

Madjid, Nurcholis (2000) Kemuliaan dan Teoritis Ibadah Islamiyah. Jakarta: Rosdakarya. Maleong, Lexy. J (1995)Metodologi Penelitian Kualitatifcet ke-5. Bandung: PT Remaja Rosdakara Mudjid, Muhaimin, Tadjab, ABD (1994) Dimensi-Dimensi Studi Islam. Surabaya: Karya Abditama. = Mukhlis Rubai dalam Ash-Shiddieqy (1992) Pedoman Shalat. Jakarta: Bulan Bintang.

\footnotetext{
${ }^{17}$ Hasbi Ash-Shiddieqy, Pedoman Shalat, (Jakarta: Bulan Bintang, 1992), hlm. 65.

${ }^{18}$ Hasil Wawancara dengan Ibu "Y" Guru BK di MTsN 2 Bukittinggi pada Tanggal 19 November 2019
} 
Nurcholi, Madjid (2000) Kemuliaan dan Teoritis Ibadah Islamiyah. Jakarta: Rosdakarya.

Prayitno (1997)Pelayanan Bimbingan dan Konseling. Jakarta: Pusat Perbukuan Depdiknas.

Situmorang, Syafrijal (2003)Pengertian Strategi Menurut Para Ahli.Jakarta: Rineka Cipta.

Sugiono (2009) Metode Penelitian Pendidikan. Bandung: Alfabeta.

Suparman, Deden (2015) Pembelajaran Ibadah Shalat Dalam Perspektif Psikis dan Medis.

Sutirna (2013) Bimbingan dan Konseling (Pendidikan formal, nonformal dan informal). Yogyakarta:

CV. ANDI OFFSET.

Tohirin (20080 Bimbingan dan Konseling di Sekolah dan Madrasah (berbasis integrasi). Jakarta: PT Raja Grafindo Persada.

Willis,Sofyan S (2004) Konseling Individual Teori dan Praktek. Bandung: CV Alfabeta.

Yusuf, Burhanuddin. “Manusia dan Amanahnya Kajian Teologis Berwawasan Lingkungan, diakses pada tanggal 14 mei 2019, pukul 16.19 WIB.

Zakiah, Darajad Dkk (1984) Dasar-Dasar Agama Islam. Jakarta: Bulan Bintang. 